\title{
Changes in the composition of digesta during passage through the small intestines of steers
}

\author{
By A. B. MCALLAN \\ National Institut? for Research in Dairying, Shinfield, Reading RG2 9AT
}

(Received 6 October 1980 = Accepted 7 May 1981)

\begin{abstract}
1. Dry matter (DM), organic natter (OM), nitrogenous constituents, carbohydrate constituents and pH were estimated in digesta taken from cight different sites in the small intestines of slaughtered steers given different diets. Amounts of constituents passing different sites were compared using cellulose as a non-digestible marker.

2. Amounts of the different constituents entering the small intestines varied with the type of diet given but the patterns of removal of each coristituent were similar regardless of diet.

3. DM and OM were removed uniformly down the length of the small intestines. Net digestibilities of 0.62 and 0.63 for DM and OM respectively of the amounts measured in segment 1 digesta (first $3 \mathrm{~m}$ post-pylorus) were found at the terminal ileum. DM and OM contents of segment 1 digesta were 5 and $8 \%$ higher respectively than in abomasal digesta. Significantly smaller anounts of digesta were found in the proximal quarter of the small intestines than in more distal sections. There was a $10 \%$ addition of water to digesta in segment 1 compared with abomasal digesta. Of the water entering the small intestines a net $65 \%$ was absorbed therein, most absorption occurring in the first half.

4. Ammonia nitrogen was removed uniformly down the length of the small intestines to a net extent of $75 \%$ of that in segment 1 digesta. There was an apparent increase of approximately $18 \%$ in the total $N$ (TN) content of segment 1 digesta compared ' $w$ ith abomasal digesta. There was an approximate net removal of $80 \%$ of the TN measured in segment 1 digesta during passage down the small intestines. Over $95 \%$ of the digestible TN was removed in the section of tract between 3 and $15 \mathrm{~m}$ from the pylorus. Net removal of nucleic acid N (NA-N) up to the distal ileum was $78 \%$ of that in segment 1 digesta, most removal occurred in the proximal quarter of the small intestine. Little or no net loss of diaminopimelic acid-N (DAP-N) occurred in the small intestine.

5. Of the carbohydrates entering the small intestines, there was little or no removal of rhamnose, arabinose or xylose. Net removal of ribose, mannose, galactose and 'starch' glucose up to the distal ileum was $82,76,54$ and $70 \%$ respectively of the amounts found in segment 1 digesta. All disappeared uniformly down the length of the small intestine.
\end{abstract}

The relative importance of the different compartments of the total digestive tract of ruminants in the utilization of nutrients has been examined by a number of workers (eg. Boyne et al. 1956; Bruce et al. 1966; Bertoni et al. 1976). Post rumen digestion of nitrogenous and carbohydrate constituents have been the subjects of recent reviews (Bergen, 1978; Armstrong \& Smithard, 1979; Smith, 1979). However, the relative importance of different parts of the small intestines is still uncertain.

Different areas of the small intestines of ruminants are of different importance in the absorption of minerals (Kay \& Pfeffer, 1969), the degradation of protein and absorption of nitrogen (Badawy et al. 1958; Ben-Ghedalia et al. 1974; Tagari \& Bergmann, 1978) and in the degradation of nucleic acids (McAllan, 1980). Similarly, differences in the passage of water through and the amounts of total digesta found within different sections of the small intestines have been observed (Elsden et al. 1945-6; Badawy et al. 1958; Grovum \& Williams, 1973). Kay (1969) discussed various factors affecting digestion in the small intestines of ruminants and drew attention to the very limited amount of information available. Most of the results currently available have been obtained with sheep. The present work was undertaken to provide comparable information for steers. 
Table 1. Steer ages $(d)$, weights $(\mathrm{kg})$, lengths of small intestines $(\mathrm{m})$ and weights of digesta $(\mathrm{kg})$ removed from the small intestines

(Results are mean values with their standard errors for three steers on diets $A$ and $C^{*}$ and two steers on diets $B$ and $D^{*}$ )

\begin{tabular}{|c|c|c|c|c|c|c|c|c|}
\hline \multirow[b]{2}{*}{ Diet } & \multicolumn{2}{|c|}{ Age (d) } & \multicolumn{2}{|c|}{ Weight $(\mathrm{kg})$} & \multicolumn{2}{|c|}{$\begin{array}{l}\text { Length of } \\
\text { small intestine (m) }\end{array}$} & \multicolumn{2}{|c|}{$\begin{array}{l}\text { Total wt of } \\
\text { digesta }(\mathrm{kg})\end{array}$} \\
\hline & Mean & SE & Mean & SE & Mean & SE & Mean & SE \\
\hline A & 351 & 8 & 193 & 10 & 22.6 & $2 \cdot 7$ & $3 \cdot 13$ & 0.43 \\
\hline B & 341 & 16 & 239 & 2 & $24 \cdot 7$ & $2 \cdot 7$ & 3.01 & 0.18 \\
\hline $\mathrm{C}$ & 326 & 42 & 195 & 20 & 21.4 & $3 \cdot 2$ & $3 \cdot 17$ & 0.27 \\
\hline D & 340 & 12 & 206 & 36 & $25 \cdot 6$ & $4 \cdot 0$ & 2.88 & 0.20 \\
\hline
\end{tabular}

* For details, see Table 2.

Table 2. Daily intakes $(\mathrm{kg})$ of the main dietary components

(Results are mean values with their standard errors for three steers receiving diets $A$ and $C$ and two steers receiving diets $B$ and $D$; each individual steer value was a mean covering the $3 \mathrm{~d}$ before slaughter)

\begin{tabular}{|c|c|c|c|c|c|c|c|c|}
\hline \multirow{2}{*}{$\begin{array}{l}\text { Diet ... } \\
\text { Component }\end{array}$} & \multicolumn{2}{|c|}{ A } & \multicolumn{2}{|c|}{ B } & \multicolumn{2}{|c|}{$\mathrm{C}$} & \multicolumn{2}{|c|}{ D } \\
\hline & Mean & SE & Mean & SE & Mean & SE & Mean & SE \\
\hline Hay & 1.80 & 0.07 & 1.95 & $0-00$ & - & - & - & - \\
\hline Dried grass & - & - & - & - & - & - & 3.90 & 0.00 \\
\hline Flaked maize & 1.79 & 0.07 & 1.66 & 0.00 & - & - & - & - \\
\hline Barley-straw pellets & - & - & - & - & 3.44 & 0.16 & - & - \\
\hline Soya-bean flour & 一 & - & - & - & 0.48 & 0.02 & - & - \\
\hline Decorticated groundnut meal & - & - & 0.44 & $0 \cdot 00$ & - & - & - & - \\
\hline
\end{tabular}

\section{METHODS \\ Animals and diets}

Ten male Friesian steers were used. Details of ages and weights are presented in Table 1. Eight were equipped with simple abomasal cannulas. Groups of three were each given diets A or C and groups of two were given diets B and D. Dietary details and intakes are given in Table 2. The diets were given in two equal feeds/d at 08.00 and 17.00 hours for at least 3 weeks before the experiment. Polyethylene glycol (molecular weight $4000 ; 30 \mathrm{~g}$ ) was added to each feed for a period of $8 \mathrm{~d}$ before slaughter.

\section{Sample collection}

The steers were slaughtered 3-4 h after the morning feed by injecting an overdose of sodium pentobarbitone solution ( $100 \mathrm{mg} / \mathrm{kg}$ body-weight) and the small intestines were completely dissected as described by McAllan (1980). The small intestines were measured, divided into eight segments of approximately equal length and numbered 1-8 from the proximal duodenum to the terminal ileum. The digesta from each segment was carefully removed, weighed and stored for analysis. Details of intestine lengths and digesta weights are given in Table 1. 
Table 3. Concentrations of dry matter (DM) and organic matter $(O M)(\mathrm{g} / \mathrm{kg}$ net digesta) and nitrogenous constituents $(\mathrm{mg} / \mathrm{kg}$ net digesta) in digesta from segment 1

(Results are mean values vith their standard errors for three steers on diets $\mathrm{A}$ and $\mathrm{C}^{*}$ and two steers on diets $B$ and $D^{*}$. Al:io shown are total mean values with standard errors for the ten steers)

\begin{tabular}{|c|c|c|c|c|c|c|c|c|c|c|}
\hline \multirow[b]{2}{*}{ Diet ... } & \multicolumn{2}{|c|}{$\mathbf{A}$} & \multicolumn{2}{|c|}{$\mathbf{B}$} & \multicolumn{2}{|c|}{ C } & \multicolumn{2}{|c|}{ D } & \multicolumn{2}{|c|}{ All } \\
\hline & Mean & SE & Mean & SE & Mean & SE & Mean & SE & Mean & SE \\
\hline DM & 58.5 & 3.6 & $53 \cdot 6$ & $1 \cdot 5$ & $63 \cdot 8$ & $3 \cdot 1$ & $58 \cdot 3$ & 0.9 & 58.9 & $2 \cdot 1$ \\
\hline OM & $51 \cdot 2$ & $2 \cdot 9$ & $45 \cdot 5$ & $1 \cdot 3$ & $54 \cdot 1$ & 2.9 & $51 \cdot 3$ & $1 \cdot 0$ & $50 \cdot 5$ & 2.0 \\
\hline Total nitrogen & 2560 & 310 & 4310 & 70 & 3329 & 679 & 3651 & 532 & 3464 & 398 \\
\hline Ammonia-nitrogen & 196 & 38 & 200 & 17 & 207 & 60 & 195 & 4 & 200 & 22 \\
\hline Nucleic acid-N & 118 & 13 & 315 & 51 & 181 & 22 & 425 & 17 & 237 & 40 \\
\hline DAP-N & 8 & 2 & 22 & 4 & 13 & 2 & 27 & 3 & 18 & 4 \\
\hline
\end{tabular}

* For details, see Table 2.

Abomasal samples were: obtained from those animals with abomasal cannulas just before slaughter by removing the cap and allowing digesta to flow out. Rumen samples were taken immediately after slaughter.

\section{Analytical methods}

Dry matter (DM), organic matter (OM) and diaminopimelic acid (DAP) were determined as described by Smith et al. (1978). Total and ammonia-N were estimated as described by Smith \& McAllan (1970) and carbohydrates by the procedures of McAllan \& Smith (1977). Nucleic acids (NA) were determined according to McAllan \& Smith (1969) and PEG by the procedure of Smith \&. McAllan (1971). The use of cellulose as an indigestible marker in the small intestine of steers was validated by McAllan (1980).

\section{RESULTS}

\section{Small intestine length and digesta content}

Details of intestine lengtins and digesta weights are given in Table 1. The animals were slaughtered at approximately similar ages and weights but the length of the small intestine appeared to be related to the weight of the animals. Extreme intestinal lengths of 18.4 and $29.5 \mathrm{~m}$ were obtained frcm steers weighing 175 and $242 \mathrm{~g}$ respectively. The mean length of small intestine of the ten steers related to body weight was $113.8 \pm 4.4 \mathrm{~m} / 1000 \mathrm{~kg}$ body-weight.

It was observed during the removal of digesta that the amounts in some of the different segments were quite variable. Parts of the tract contained no digesta. These portions varied in length from approximately $0.5-4.0 \mathrm{~m}$. Because the small gut was divided into eight segments, on occasion some segments contained no digesta but these comprised only approximately $4 \%$ of the total number of segments. Other segments contained relatively small (less than $70 \mathrm{~g}$ ) amciunts of digesta. Empty or partially filled segments were observed in seven of the ten intestinis but these were always confined to the proximal half. On average, the proportions of the total small intestine digesta found in segments 1,2 and 4 were 0.06 , 0.10 and 0.15 respectively. The amounts of digesta in segment 1 were significantly lower than those in segment $2(P<0.01)$ and $4(P<0.001)$. Amounts of digesta in segments $5-8$ were similar to that found in segment 4 .

$$
D M, O M, \text { water and } p H
$$

Concentrations of DM and OM measured in digesta from segment 1 of the steers are given in Table 3. Both varied depending on the diet. Patterns of removal in the small intestines 


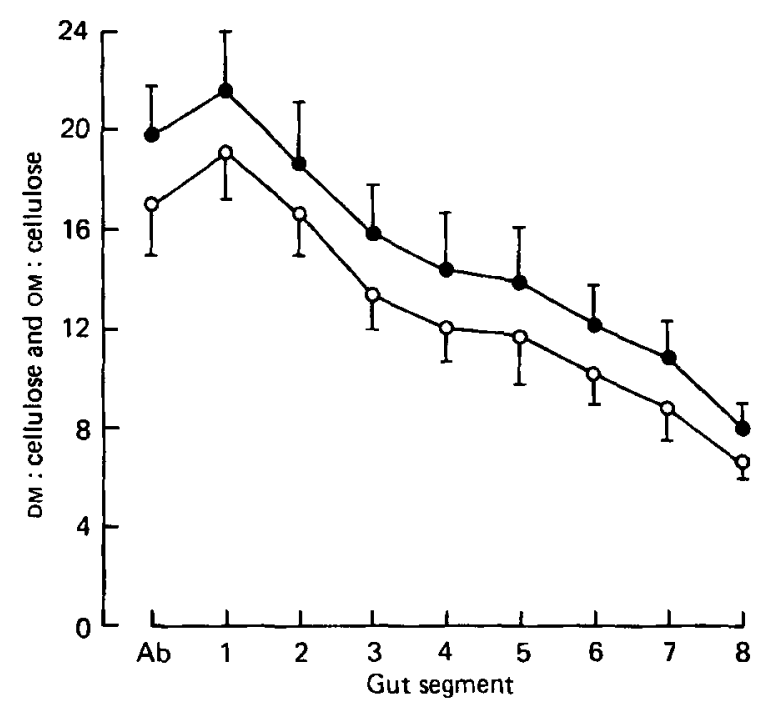

Fig. 1. Dry matter (DM; ) and organic matter $(\mathrm{OM} ; O)$ :cellulose in abomasum and eight segments of small intestinal digesta of steers. Results are mean values for eight animals (abomasal digesta) or ten animals (small intestine digesta), with the standard errors of the means represented by vertical bars.

were similar for all four diets and over-all mean values for ten steers are presented in Fig. 1. Both DM and OM were removed evenly from the digesta in all segments. The proportions of the totals measured in segment 1 digesta which were removed in the small intestines were 0.62 and 0.63 for DM and OM respectively. In comparing the composition of digesta from segment 1 with that of the abomasum it appeared that there were small additions of DM and $\mathrm{OM}$ in the proximal duodenum of approximately 5 and $7 \%$ respectively.

Addition of water also occurred in segment 1 digesta compared with abomasal digesta of the order of $10-12 \%$. The pattern of water absorption in the small intestines is shown in Fig. 2. Approximately $70 \%$ (net) of the water in segment 1 digesta was removed by the terminal ileum. Over half the total water absorption, including the secretions in segment 1, disappeared in segments $2-4$ (ie. between 6 and $12 \mathrm{~m}$ post pylorus).

Digesta $\mathrm{pH}$ values are shown in Fig. 3 for the ten steers. Mean rumen values varied from 6.63 in animals receiving diet $\mathrm{A}$ (Table 2) to 6.90 in animals receiving diet $\mathrm{B}$ (Table 2). Extreme individual rumen $\mathrm{pH}$ values ranged from 6.48 to 7.01 . Mean abomasal digesta $\mathrm{pH}$ values varied between $2 \cdot 50$ in steers receiving diet $\mathrm{B}$ (Table 2) and 3.17 in steers receiving diet $\mathrm{C}$ (Table 2) with an over-all mean of 2.90 . For segment 1 digesta, dietary mean $\mathrm{pH}$ values varied from 5.49 (diet D, Table 2) to 5.92 (diet C, Table 2) with an over-all mean of 5.69. The $\mathrm{pH}$ of digesta then increased gradually between segments 2 and 4 , reaching a value of approximately $7 \cdot 30$ and then remained relatively constant to the end of the ileum (segment 8).

\section{Nitrogenous constituents}

TN, $\mathrm{NH}_{3}-\mathrm{N}, \mathrm{NA}-\mathrm{N}$ and DAP-N were estimated in digesta from segment 1 of the steers. Mean values for each diet and over-all mean values for the ten steers are shown in Table 3. $\mathrm{NH}_{3}-\mathrm{N}$ concentrations were similarly low on all diets whereas the amounts of the other nitrogenous constituents varied markedly with the diet. Like other components however the patterns of removal from the small intestines were similar irrespective of the amounts initially present. Therefore over-all patterns of removal are presented in Fig. 4. 


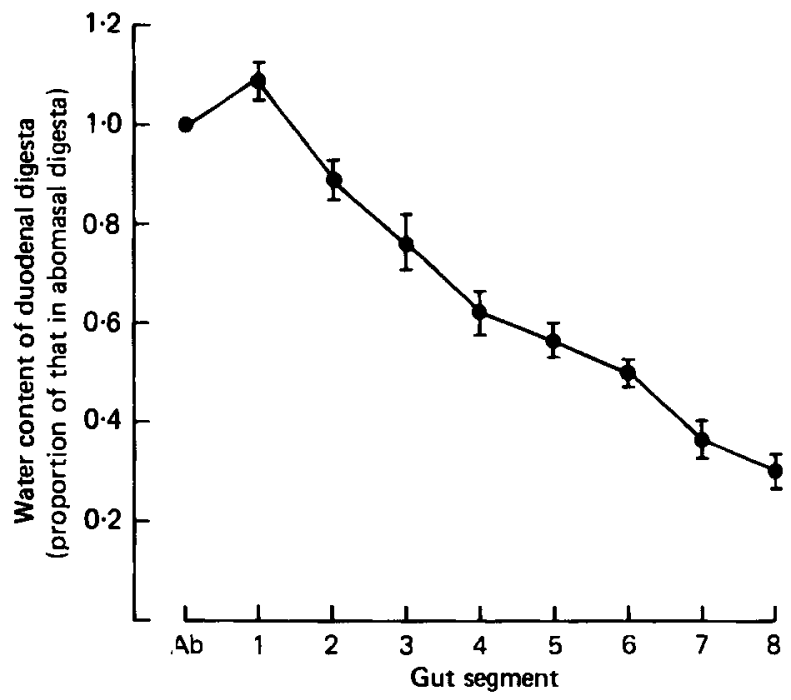

Fig. 2. Water content of Jigesta from the abomasum (Ab) and eight segments of the small intestines of steers (proportion of that in abomasal digesta). Results are mean values for eight animals (Ab) or ten animals (small intestine segments) with the standard errors of the means represented by vertical bars.

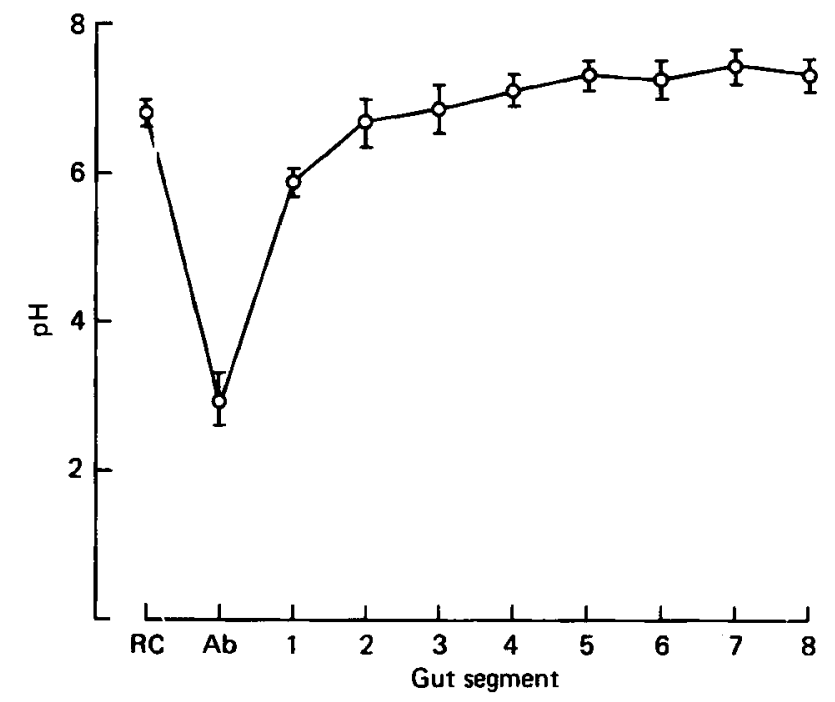

Fig. 3. $\mathrm{pH}$ of digesta from the rumen (RC) abomasum (Ab) and eight segments of the small intestines of steers. Results are mez.n values for ten animals (RC and small intestine) or eight animals (Ab) with the standard error of the means represented by vertical bars.

$\mathrm{NH}_{3}-\mathrm{N}$ disappeared fairly uniformly down the tract and an approximate net $75 \%$ had disappeared at the terminal ileum. There was an apparent increase in TN content in digesta from segment 1 of approximately $18 \%$ compared with that in abomasal digesta. An approximate net $80 \%$ of TN estimated in segment 1 digesta had been removed by the terminal ileum. Over $90 \%$ of the digestible $\mathrm{N}$ had disappeared by segment 5 (i.e. $15 \mathrm{~m}$ from the pylorus).

NA-N disappeared rapidly, primarily in the proximal quarter of the small intestine. Over-all 


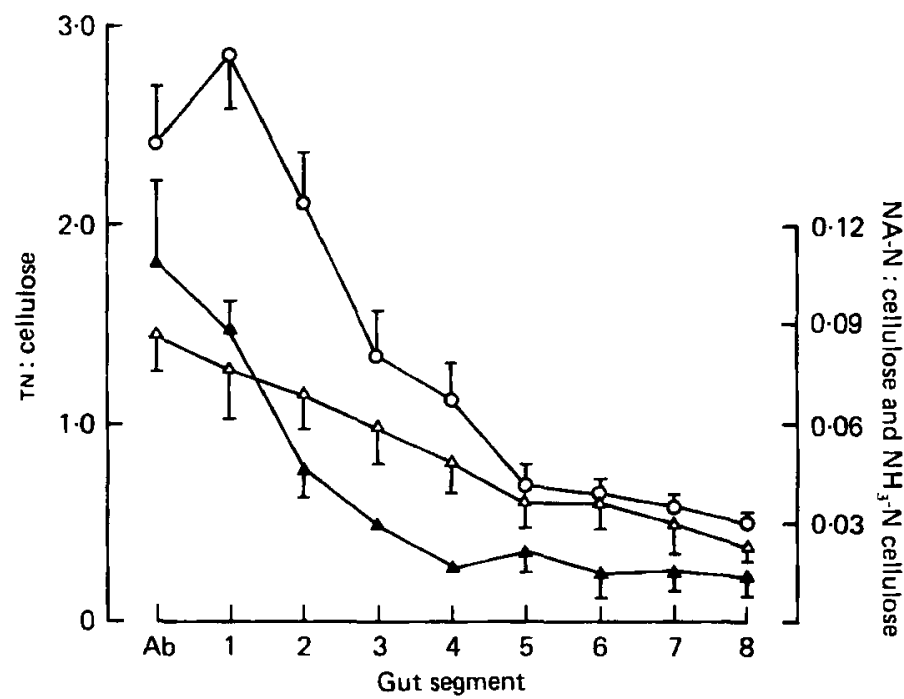

Fig. 4. Ratio total nitrogen (TN; $O$ ), nucleic acid-N (NA-N; $\Delta$ ) or ammonia-N $(\Delta)$ : cellulose in digesta from the abomasum $(\mathrm{Ab})$ and eight segments of the small intestines of steers. Results are mean values for eight steers $(\mathrm{Ab})$ or ten steers (small intestine segments) with the standard errors of the means represented by vertical bars.

Table 4. Carbohydrate composition ( $\mathrm{mg} / \mathrm{kg}$ digesta) of digesta from segment 1 of the small intestines of steers

(Results are mean values with their standard errors for three steers receiving diets $\mathrm{A}$ and $\mathrm{C}^{*}$ and two steers receiving diets $B$ and $D^{*}$. Also shown are the over-all mean values with their standard errors for all ten steers)

\begin{tabular}{|c|c|c|c|c|c|c|c|c|c|c|c|c|c|c|}
\hline \multirow[b]{2}{*}{ Diet } & \multicolumn{2}{|c|}{ Rhamnose } & \multicolumn{2}{|c|}{ Ribose } & \multicolumn{2}{|c|}{ Mannose } & \multicolumn{2}{|c|}{ Arabinose } & \multicolumn{2}{|c|}{ Galactose } & \multicolumn{2}{|c|}{ Xylose } & \multicolumn{2}{|c|}{$\begin{array}{l}\text { Starch- } \\
\text { glucose }\end{array}$} \\
\hline & Mean & SE & Mean & SE & Mean & SE & Mean & SE & Mean & SE & Mean & SE & Mean & SE \\
\hline $\mathbf{A}$ & 130 & 26 & 188 & 87 & 138 & 36 & 768 & 242 & 785 & 43 & 2536 & 719 & 2822 & 659 \\
\hline B & 78 & 20 & 304 & 17 & 201 & 14 & 396 & 51 & 509 & 13 & 1500 & 395 & 1179 & 180 \\
\hline C & 108 & 16 & 352 & 124 & 162 & 31 & 494 & 190 & 700 & 301 & 1687 & 301 & 2607 & 791 \\
\hline D & 59 & 27 & 331 & 110 & 166 & 71 & 300 & 74 & 623 & 326 & 1711 & 392 & 609 & 73 \\
\hline All & 89 & 15 & 286 & 42 & 163 & 17 & 518 & 90 & 663 & 87 & 1900 & 364 & 1986 & 378 \\
\hline
\end{tabular}

* For details, see Table 2.

net removal of NA-N as a percentage of that measured in segment 1 was $78 \%$. It was not possible to estimate DAP in all segments of all animals and less than half the animals were examined post-segment 1 . There appeared to be little or no removal of DAP-N from digesta during passage down the small intestine. However the results obtained were extremely variable and losses estimated to occur in the small intestines varied from $25 \%$ to $-28 \%$.

\section{Carbohydrate constituents}

Virtually all the carbohydrates entering the small intestines were in bound forms. These were released by acid hydrolysis and estimated as monosaccharide units. The carbohydrate 


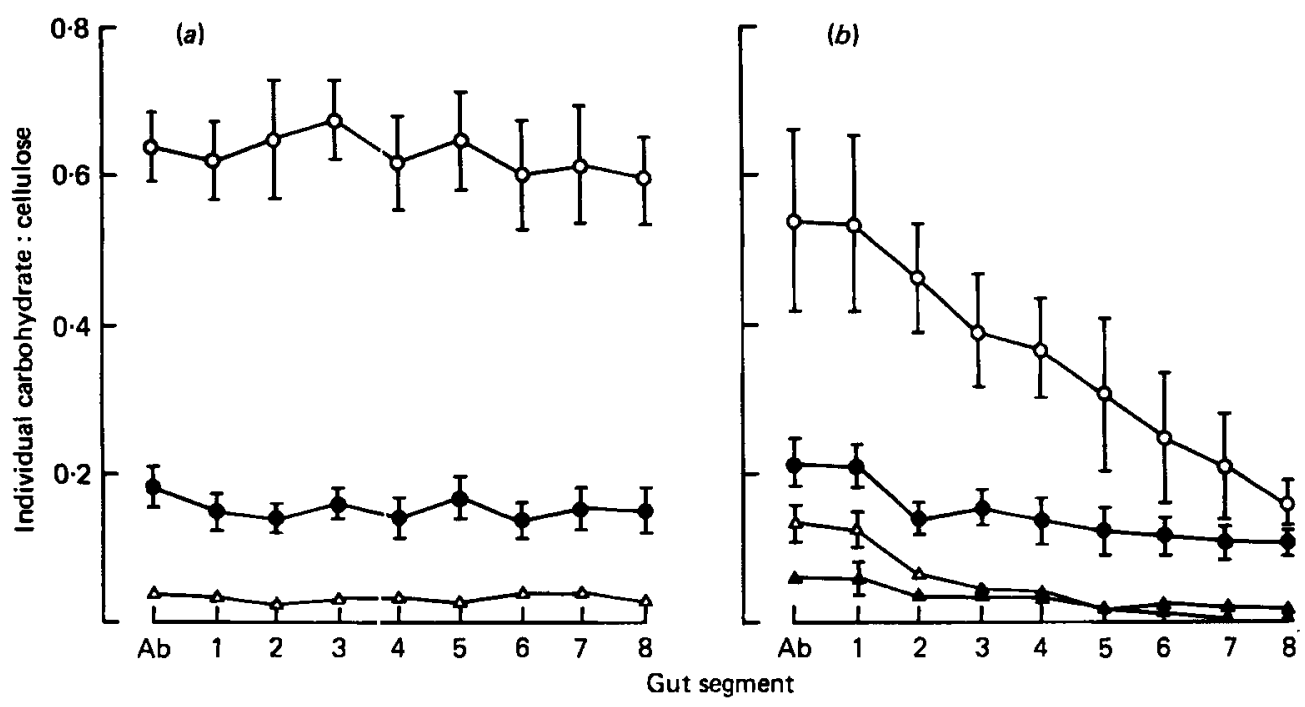

Fig. 5. Ratio individual carbohydrate:cellulose in digesta from the abomasum $(\mathrm{Ab})$ and eight segments of the small intestine of steers. (a) Rhamnose $(\Delta)$, arabinose (O), xylose $(O)$; $(b)$ 'starch'-glucose $(O)$; galactose $(O)$, ribose $(\triangle)$. mannose $(\Delta)$. Results are mean values for eight steers $(A b)$ and ten steers (small intestine segments), with the standard errors of the means represented by vertical bars (for clarity bars, values less than $10 \%$ are not shown in Fig. $5 b$.

compositions of digesta from segment 1 of steers receiving different diets are shown in Table 4. Appreciable differences were found in the concentrations of some of the sugars, depending on the diet. However, the patterns of removal of the individual carbohydrates in the small intestines were similar irrespective of diet. Mean disappearances of sugars are shown in Fig. 5. There was little or no removal of rhamnose, arabinose or xylose in the small intestines. The other sugars were removed to varying extents. The amounts of ribose, mannose, galactose and 'starch'-glucose found in digesta from segment 8 were 17, 24, 44 and 30\% respectively of those in segment 1 digesta. For 'starch '-glucose, mannose and galactose their removal appeared to occur fairly uniformly down the entire length of the small intestine. Ribose was removed in a similar pattern to NA-N. Approximately $50 \%$ of the net total removed in the small intestines had disappeared by segment 2 .

\section{DISCUSSION}

Although the total lengths of the small intestines of the steers used in this work (approximately $24 \mathrm{~m}$ on average) were similar to those found in sheep (Badawy et al. 1958; Nickel et al. 1973) the total content of digesta in the steers was appreciably greater. In adult sheep weighing 40-60 kg. the weight of digesta in the small intestines was approximately 0.65-0.95 kg (Boyne et ai. 1956; Grovum \& Williams, 1973) whereas in the steers it varied from $2 \cdot 7-3 \cdot 5 \mathrm{~kg}$. However it has been shown that the contents of the small intestines of sheep were related to dietary intakes (Grovum \& Williams, 1973) and the steers in the present study were receiving three to four times the amounts of food received by the sheep. Relationships between IIM intakes and total small intestine contents were found to be very variable. With sheep receiving all roughage or roughage plus concentrate diets, total net weight of digesta in the small intestines, expressed as a proportion of intake, varied from 0.53 to 0.97 (Boyne et al. 1956; Grovum \& Williams, 1973). Values from cattle receiving chopped whole sugar cane diets with energy or nitrogen supplements or both ranged from 
0.48 to 1.00 (Minor et al. 1977 ) and in the present study with steers were $0.75-0.87$. When, under 'normal' feeding conditions, the total weights of wet digesta in the small intestines of sheep or cattle were expressed as a percentage of body-weight they ranged from 1.3-1.6 and 1.0 1.2 respectively (Boyne et al. 1956; Grovum \& Williams, 1973; Minor et al. 1977). Values of 1.2 to $1.6 \%$ (mean $1.4 \%$ ) were obtained for the ten steers used in this study. It seems possible that with sufficient information it should be possible to calculate approximately the total amount of digesta in the small intestines from body-weights.

Significantly smaller amounts of digesta were found in the proximal part of the small intestines compared with the central and distal segments of steers as has already been reported for sheep (Elsden et al. 1945-6; Badawy et al. 1958; Grovum \& Williams, 1973).

Mean DM contents of proximal duodenal digesta and distal ileal digesta of 5.9 and $8.4 \%$ respectively were within the ranges reported for sheep duodenal and ileal digesta of 4.1-6.0 and 6.3-9.3\% respectively (Hogan \& Phillipson, 1960; Bruce et al. 1966; Grovum \& Williams, 1973). Total DM and OM net digestibilities found in the present work were 0.62 and 0.63 respectively, and the disappearances of the digestible DM and digestible OM were fairly uniform throughout the entire length of the small intestine.

In the present experiment, carbohydrates from different sources (i.e. microbial or food) were not distinguished in digesta entering the small intestines. It has been shown, however, that the carbohydrates entering the small intestines of steers are virtually all in bound forms. Nearly all the rhamnose, ribose and mannose and more than half the galactose and 'starch'-glucose were contributed by bacteria, whereas virtually all the xylose, arabinose and cellulose came from the diet (McAllan \& Smith, 1974). Little or no losses of cellulose (McAllan, 1980) or hemicellulose sugars were found in the small intestines of steers during this work. This has also been found for sheep (Armstrong \& Beever, 1969; Beever et al. 1972; Armstrong \& Smithard, 1979). Net digestibility values obtained for ribose and rhamnose agree well with values obtained from other steers on similar diets (McAllan \& Smith, 1974) but greater net digestibilities were found for mannose and galactose in the present study than was found previously (McAllan \& Smith, 1974). The reason for this is unknown but the amounts of mannose and galactose entering the small intestines of the steers in this study were greater than the amounts found in the earlier work. Starch net digestibility in the small intestines of steers of approximately 0.70 was similar to that reported for steers (McAllan \& Smith, 1974) and sheep (Armstrong \& Beever, 1969; Armstrong \& Smithard, 1979). It seems clear from the present work that the digestive processes of starch degradation and absorption were active throughout at least $85 \%$ of the length of the small intestine.

There was an apparent increase of approximately $18 \%$ in the amount of TN measured in digesta from segment 1 compared with abomasal digesta similar to that reported for digesta $0.7 \mathrm{~m}$ from the pylorus compared with digesta taken only $0.05 \mathrm{~m}$ from the pylorus of cannulated sheep (Tagari \& Bergmann, 1978) but considerably less than that reported for sheep (Boyne et al. 1956; Badawy et al. 1958) or cattle (Reynaud, 1955) for animals slaughtered by shooting.

Badawy et al. (1958) attributed much of the additional $\mathrm{N}$ in sheep proximal duodenal contents to epithelial cells sloughed on shooting the sheep. It is possible that even with drugs killing, some sloughing of cells would occur but it may be of interest that there was no apparent comparable increase in NA-N accompanying the increase in TN. However, some NA degradation had occurred in digesta from segment 1 as evidenced by the appearance of breakdown products (McAllan, 1980) and it is possible that the rate of breakdown of NA in this area was much greater than the net observed amount indicated.

Total small intestine (abomasum to terminal ileum) net digestibility for TN approximately 0.75 was similar to the range of values normally found for sheep and cattle (Smith, 1979). 
However net TN digestitility of the amounts measured in segment 1 , by the terminal ileum was approximately $0 \cdot 80$. The digestibility values quoted by Smith (1979) were largely obtained with cannulated animals and it seems that the position of the sampling site in relation to the sites of $\mathrm{N}$ secretion (particularly in cattle) is extremely important in determining the initial amounts of $\mathrm{N}$ entering the small intestine and its subsequent digestibility.

Lennox \& Garton (196.8) suggested that neutralization of digesta in the duodenum of ruminants is considerably slower than in single stomached animals. It has also been suggested that the acid conditions extending well into the jejunum may limit digestion, particularly protein digestion in that there would be insufficient time for maximum proteolysis or end product absorption or both in the remainder of the small intestine. Virtually all the results in the literature on digesta $\mathrm{pH}$ in the small intestines of ruminants refer to sheep. In sheep the bile and pancreatic secretions enter through a common duct approximately $350 \mathrm{~mm}$ from the pylorus (Nickel et al. 1973) whereas in cattle the bile and pancreatic secretions are introduced separately into the intestines, the bile duct entering approximately $600 \mathrm{~mm}$ from the pylorus and the pancreatic duct approximately $350 \mathrm{~mm}$ more distally (Nickel et cil. 1973). It is possible that sites at which digesta neutralization occurs are different in cattle and sheep.

The $\mathrm{pH}$ of digesta from sheep small intestine taken from between the pylorus and bile and pancreatic duct entry' has been quoted between 2.4 and 4.8 (Harrison \& Hill, 1962; Kay, 1969; Ben-Ghedalia et al. 1974). Digesta taken from immediately post bile and pancreatic duct to the end of the duodenum (approximately $1 \mathrm{~m}$ post pylorus) has recorded pH values between 2.8 and 5.3 (Lennox \& Garton, 1968; Kay, 1969; Ben-Ghedalia et al. 1974; Lee, 1977). These vide variations may be a result of incomplete mixing of bile and pancreatic secretions with the digesta (Harrison \& Hill, 1962). This effect may be more severe in fistulated animals where there may be greater interference in the normal peristaltic mixing processes around the cannulas. Differences in the rates and amounts of digesta flowing through the proximal duodenum would probably also affect digesta $\mathrm{pH}$. No comparable results appear available on duodenal digesta $\mathrm{pH}$ in cattle.

Digesta $\mathrm{pH}$ values measured in the proximal jejunum of sheep (i.e. $2-3 \mathrm{~m}$ from the pylorus) were less variable than duodenal values and ranged from 3.8 to 5.2 (Harrison \& Hill, 1962; Lennox \& Garton, 1968; Lennox et al. 1968; Kay, 1969; Ben-Ghedalia et al. 1974). The $\mathrm{pH}$ of digesta from segment 1 (up to $3 \mathrm{~m}$ from the pylorus) of the steers in this study averaged 5.6, similar to that obtained from digesta taken $3 \mathrm{~m}$ from the pylorus of sheep (Kay, 1969; Ben-Ghedalia et al. 1974). However, the steer digesta values were an average for all the digestal from the first $3 \mathrm{~m}$ post-pylorus so the $\mathrm{pH}$ of the digesta in the third $1 \mathrm{~m}$ of intestine was presumably higher than $5 \cdot 6$.

Conversion of trypsinogen and chymotrypsinogen to their active forms occurs above $\mathrm{pH}$ 5.0 (Boyer et al. 1960) and presumably this is occurring in digesta $2-3 \mathrm{~m}$ from the pylorus of the steers in the present experiment. Nucleases, with $\mathrm{pH}$ optima approximately at neutrality similar to the proteolytic enzymes, were active in digesta from segment 1 (McAllan, 1980). It seems therefore, that in only a relatively short length of the small intestine would there exis 1 conditions completely limiting proteolytic activity by pancreatic enzymes. The importance of the need for acid conditions in the proximal duodenum as a stimulus for abomasal and pancreatic secretions and gut motility has been pointed out (Kay, 1969; Bruce \& Huber, 1973) but the length of small intestines over which these conditions are necessary :s not known and may be comparatively small.

Digestible DM, OM anid most carbohydrates were removed fairly uniformly down the whole of the small intestine apart from perhaps the first 1 or $2 \mathrm{~m}$. Of the TN digested in the small intestine on the other hand, $90 \%$ had disappeared by segment 5 (15 $\mathrm{m}$ from the 
pylorus) and $96 \%$ by segment 6 ( $18 \mathrm{~m}$ from the pylorus). Badawy et al. (1958) found that $80 \%$ of the digestible $\mathrm{N}$ had disappeared by approximately $18 \mathrm{~m}$ from the pylorus of sheep and maximum absorption of amino acids from the small intestines of sheep was calculated to occur between 7 and $15 \mathrm{~m}$ post-pylorus (Ben-Ghedalia et al. 1974).

It would seem for the steers under the conditions obtaining in this experiment that the pancreatic enzymes were not subjected to long contact with acid $\mathrm{pH}$ and that the digestible polymers were efficiently broken down and removed in the small intestines. Probably more important limitations in digestion and absorption in the small intestines would be the rate of passage of digesta (Armstrong \& Hutton, 1975) and the absolute amounts of digesta within the small intestines. These could affect values for the ratios of secreted enzymes:substrates, the time of contact between enzymes and substrates and the length of contact between end products and absorption sites.

The author thanks Dr R. H. Smith for his critical assessment of the manuscript; also $\mathrm{Dr}$ H. L. Buttle for the insertion of cannulas, Misses C. Philips and K. Smith for help with the animal experiments and Mr E. S. Griffith for skilled technical assistance.

\section{REFERENCES}

Armstrong, D. G. \& Beever, D. E. (1969). Proc. Nutr. Soc. 28, 121.

Armstrong, D. G. \& Hutton, K. (1975). In Digestion and Metabolism in the Ruminant (I. W. McDonald and A. C. I. Warner, editors). Armidale, NSW: The University of New England Publishing Unit.

Armstrong, D. G. \& Smithard, R. R. (1979). Proc. Nutr. Soc. 38, 283.

Badawy, A. M., Campbell, R. M., Cuthbertson, D. P., Fell, B. F. \& Mackie, W. S. (1958). Br. J. Nutr. $12,367$.

Beever, D. E., Coehlo da Silva, J. F., Prescott, J. H. D. \& Armstrong, D. G. (1972). Br. J. Nutr. $28,347$.

Ben-Ghedalia, D., Tagari, H., Bondi, A. \& Tadmor, A. (1974). Br. J. Nutr. 31, 125.

Bergen, W. G. (1978). Fedn Proc. Fedn Am. Socs exp. Biol. 37, 1223.

Bertoni, G., Watson, M. J., Savage, G. P. \& Armstrong, D. G. (1976). Zoo Nutr. Anim. $2,107$.

Boyer, P. D., Lardy, H. \& Myrback, K. (1960). The Enzymes, vol. 4. New York and London: Academic Press. Boyne, A. W., Campbell, R. M., Davidson, J. \& Cuthbertson, D. P. (1956). Br. J. Nutr. 10, 325.

Bruce, J., Goodall, E. D., Kay, R. N. B., Phillipson, A. T. \& Vowles, L. E. (1966). Proc. R. Soc. B $166,46$.

Bruce, L. A. \& Huber, T. L. (1973). J. Anim. Sci. 37, 164.

Elsden, S. R., Hitchcock, M. W. S., Marshall, R. A. \& Phillipson, A. T. (1945-6). J. exp. Biol. $22,191$.

Grovum, W. L. \& Williams, V. J. (1973). Br. J. Nutr. 29, 13.

Harrison, F. A. \& Hill, K. J. (1962). J. Physiol., Lond. 162, 225.

Hogan, J. P. \& Phillipson, A. T. (1960). Br. J. Nutr. 14, 147.

Kay, R. N. B. (1969). Proc. Nutr. Soc. 28, 140.

Kay, R. N. B. \& Pfeffer, E. (1969). In Physiology of Digestion and Metabolism in the Ruminant (A. T. Phillipson, editor). Newcastle-upon-Tyne: Oriel Press Limited.

Lee, G. J. (1977). Aust. J. agric. Res. 28, 1075.

Lennox, A. M. \& Garton, G. A. (1968). Br. J. Nutr. 22, 247.

Lennox, A. M., Lough, A. K. \& Garton, G. A. (1968). Br. J. Nutr. 22, 237.

McAllan, A. B. (1980). Br. J. Nutr. 44, 99.

McAllan, A. B. \& Smith, R. H. (1969). Br. J. Nutr. 23, 671.

McAllan, A. B. \& Smith, R. H. (1974). Br. J. Nutr. 31, 77.

McAllan, A. B. \& Smith, R. H. (1977). Br. J. Nutr. 37, 55.

Minor, S., MacLeod, N. A., Preston, T. R. \& Leng, R. A. (1977). Trop. Anim. Prod. 2, 163.

Nickel, R., Schummer, A. \& Seiferle, E. (1973). The Viscera of the Domestic Mammals. (Translated and revised by W. O. Sack). Berlin-Hamburg: Verlag Paul Parey.

Reynaud, P. (1955). Arch. Sci. physiol. 9, 35.

Smith, R. H. (1979). J. Anim. Sci. 49, 1604.

Smith, R. H. \& McAllan, A. B. (1970). Br. J. Nutr. 24, 545.

Smith, R. H. \& McAllan, A. B. (1971). Br. J. Nutr. 25, 181.

Smith, R. H., McAllan, A. B., Hewitt, D. \& Lewis, P. L. (1978). J. agric. Sci., Camb. 90, 557.

Tagari, H. \& Bergmann, E. N. (1978). J. Nutr. 108, 790. 